\title{
福島県農協共済福祉事業団による健康増進活動 について
}

\author{
田中美恵子*, 白石 光子*, 吉田 洋 一, 生田目 苊明,

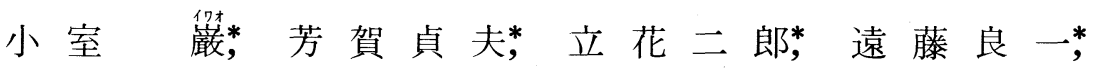 \\ 菊 田重 治,** 赤 沼 克 也,**
}

\section{I 、はじめに}

昭和57年度, 福島県農協共済福祉事業団（以下，事 業団と略称する）による，健康増進活動に参加した組 合員 5,344 名に対して行なった諸検査項目の異常者率に ついて検討，報告する。

\section{II． 検診体制及び検診内容について}

\section{1）事業団について}

昭和 54 年 3 月, 県内 48 組合の組合員約 4,000 戸を対象 に農協生活福祉活動に関するアンケートを行なった。 その結果「常日頃，不安を感じていることがあります か」といら問いに汪とんどの人 (87.2\%) が，何か不 安をもって抢り，その理由としては，「病気」「事故」

「子供の先行」「老後の生活」等が挙げられた。また「農 協に望む福祉活動」としては,「健康診断活動」「健康 保養活動」等, 健康問題解決の要望が強く出された。 これに応觉るべく，財団法人「福島県農協共済福祉事 業団」が，昭和55年に設立された。この活動のための 基金は，基本財産 1 億円（全額共済連出資）五力年計 画で，約 9 億円を見こみ各連合会，各単位農協及び農 協共済契約者からの寄付金によって，調達，造成する こととした。

主な活動は，(1)健康增進体制，(2)検診活動体制の強 化活動，(3)交通安全対策活動，(4)災害救援活動，(5)小 域福祉活動の支援，(6)その他この法人の目的を達成す るために必要な活動などである。

このうち, 健康増進活動を昭和56年より事業団の要 請をらけて,「厚生連・農村医学研究所」(以下, 農医 研と略称する) が，健診を担当している。

2) 検診内容

\section{* 農村医学研究所}

** 鹿島厚生病院

***双葉厚生病院

（受付：昭和59年 5 月 19 日)
(1)対象：県下の農家組合員（農村地域住民を含む）, 特に生計中心者を主体とする。

(2)事業団が選定した県内の公的保養施設と利用契約 を締結し，年間計画で，一定の利用者を一泊二日の日 程で行なら。

(3)内容：血圧, 検尿 (蛋白, 糖, ウロビリノーゲン), 血色素, 総コレステロール, 中性脂肪, GPT, コリン エステラーゼ, 肥満度, 皮下脂肪厚, 医師による診察, 指導（聴打診を含む，必要に応じて心電図）を農医研 が担当し, 身長, 体重, 座高, 握力, 背筋力, 立位体 前屈, 肺活量, 脈拍等を事業団が計測した。

3 ）日程

単位農協ごと50８８名をまとめ，中央会を通し，事 業団に申し込をれたものを年間の日程として確定す る。当日, バスなどで県内の特定された施設へ，農協 生活指導員などの付添により，朝食抜さで集合する。

第 1 日目, 午前 9 時 30 分 10 時に受付, 検診の説明 が事業団よりされた後, 採尿, 採血, 問診, 身体計測, 体力測定, 血圧測定を行ない昼食となる。午後 1 時よ り医師による診察があり，3 時より 1 時間の健康講話, 4 時より保健婦, 生活指導員などによる生活講話があ り, 講評後, 休息, 夕食となる。

生化学検查を含む，すべての結果は第 1 日午後 1 時 よりの診察までに個人の成績表に記入し，診断後本人 へ渡す。午後 3 時よりの講話は自分の結果を見ながら 聞くことができる。その対応として，血色素測定は，

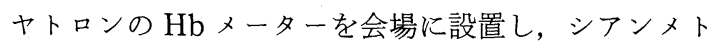
へモグロビン法により行ない，また生化学検査 はำTBA360型自動分析装置をマイクロバスに搭載し, 脂質は酵素法, コリンエステラーゼは，初速度測定法 一DTNB 法, GPT は初速度測定法一Karmen 法で行 なった。

第 2 日目, 午前 7 時より体操講師を招き体操を行な い, 朝食後解散する。な和解散時, 精密検査, 治療を 必要とする者へ,「精密検查結果通知書紹介状」を渡し, 精查受診を指導した。 


\section{III. 検 査 成 績}

1）年令, 性別受診者数

図 $1 \mathrm{~A}$ は，年令性別の受診者率を表わしたものであ る。女性 3,803 名 (71.2\%)，男性1,541名 (28.8\%) と 圧倒的に女性が多い。図 $1 \mathrm{~B}$ の年令別に打いて，男性 50 代 (36.3\%)，60代 (25.7\%)，40代 (21.7\%) の順 であり，女性 50 代 (49.6\%)40代(26.5\%), 60代(16.3\%) の順となり，いずれも中高年層に多ふった。

2 ）血圧異常者（図 2)（表 1)

WHO の基準によって分類した。全体的にみれば, 男 女とも年令を括らごとに血圧異常者が多くみられ，特

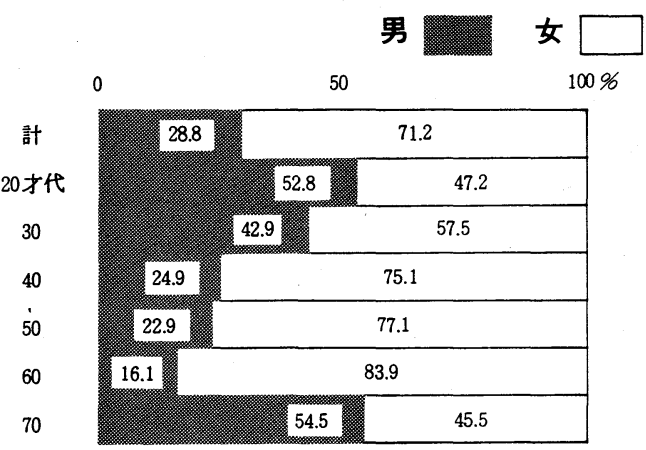

·図1 A．年令・性別受診者率

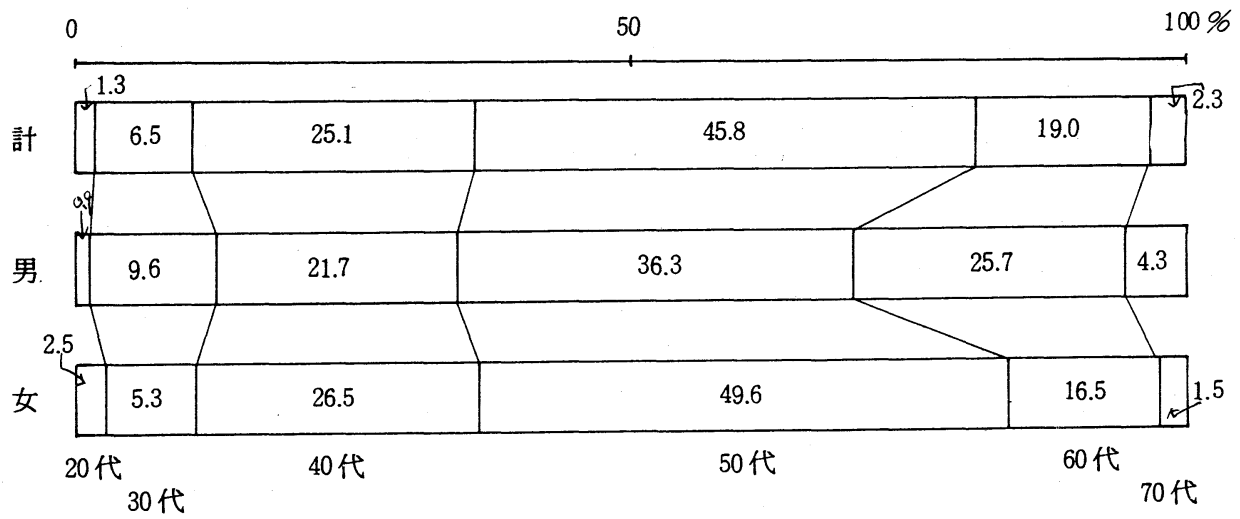

図 1 B. 年令 ·性別受診者率

表 1.WHO 血圧分類

\begin{tabular}{c|c|c|c|c|c}
\hline & $\mathrm{N}$ & $\mathrm{P}_{1}$ & $\mathrm{P}_{2}$ & $\mathrm{P}_{3}$ & $\mathrm{P}_{4}$ \\
\cline { 2 - 6 } & 正 常 & 境界線 & $\begin{array}{c}\text { 高血圧 } \\
\mathrm{A}\end{array}$ & $\begin{array}{c}\text { 高血圧 } \\
\mathrm{B}\end{array}$ & $\begin{array}{c}\text { 高血圧 } \\
\mathrm{C}\end{array}$ \\
\hline $\begin{array}{c}\text { 最大 } \\
\text { 血圧值 }\end{array}$ & $100 \sim 139$ & $140 \sim 159$ & $160 \sim 179$ & $180 \sim 199$ & 200 以上 \\
\hdashline $\begin{array}{c}\text { 最尔 } \\
\text { 血圧值 }\end{array}$ & $60 \sim 89$ & $90 \sim 94$ & $95 \sim 99$ & $100 \sim 109$ & 110 以上 \\
\hline
\end{tabular}

最大，最小血圧値の一方又は両者，一方の場合は

P 数の多い方讁応

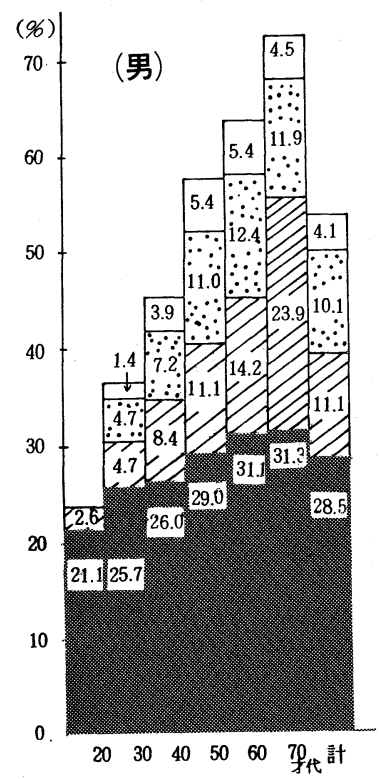

図 2，血

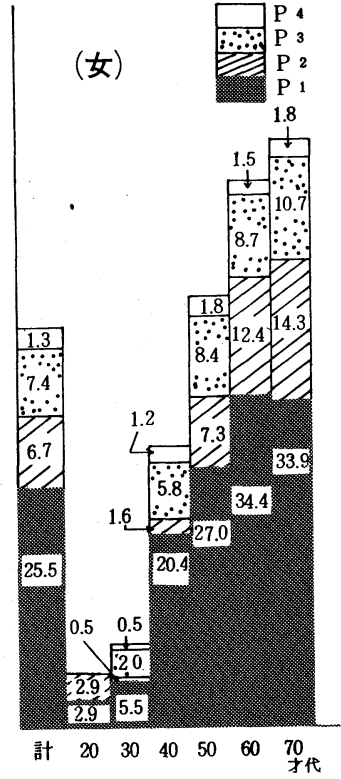

圧 
に女性に括いて著明であり，20代 $5.8 \% ， 30$ 代 $8.5 \%$ ， 40 代 $30.5 \%, 50$ 代 $44.0 \% ， 60$ 代 $57.0 \% ， 70$ 代 $60.7 \%$ だっ た。また総合的に異常者率は，男性 $53.8 \%$ ，女性 $40.6 \%$ であり，他検査に比し多かった。男性は「趾」では， 20 代 $21.1 \% ， 30$ 代 $25.7 \% ， 40$ 代 $26.0 \% ， 50$ 代 $29.0 \%$ ， 60 代 $31.1 \% ， 70$ 代 $31.3 \%$ とあまり年令差がないが， $\left\lceil\mathrm{P}_{2}, \mathrm{P}_{3}\right\rfloor$ は，20代 $2.6 \% ， 30$ 代 $9.5 \% ， 40$ 代 $15.9 \%$, 50 代 $23.1 \% ， 60$ 代 $26.6 \% ， 70$ 代 $35.8 \%$ と年令を追う毎 に増加した。

3）血清脂質異常者率（図 $3 \mathrm{~A}$ ，図 $3 \mathrm{~B}$ )

総コレステロールは, $130 \sim 220 \mathrm{mg} / \mathrm{d} \ell$ を, 中性脂肪 は，55～ $150 \mathrm{mg} / \mathrm{d} \ell$ を正常範囲とした。男性は，年令 に無関係で, 約 $20 \%$ の平均した異常者率を示し, 中性 脂肪は， $210 \mathrm{mg} / \mathrm{d} \ell$ 以上の範囲では20代 $2.6 \% ， 30$ 代 $16.3 \%, 40$ 代 $14.7 \%, 50$ 代 $8.6 \%, 60$ 代6.3\%，70代 $4.5 \%$ と加令減少を示していた。女性では，総コレステロー ル異常者は，20代 $5.9 \% ， 30$ 代 $17.0 \% ， 40$ 代 $24.5 \% ， 50$ 代 $42.6 \% ， 60$ 代 $47.8 \% ， 70$ 代 $54.5 \%$ ，中性脂肪異常者 は30代 $5.0 \% ， 40$ 代 $10.0 \% ， 50$ 代 $19.5 \% ， 60$ 代 $27.9 \%$, 70 代 $36.3 \%$ と，ともに加令増加が著明であり，特に50 代より急増した。

4) トランスアミナーゼ (GPT) 異常者率（図 4)

1 ～23IU/ $\ell$ を正常範囲とした。女性の異常者は, 各 年令層とも $10 \%$ 以下と少ないのに対し，男性の異常者 率はその 3〜 倍を示した。特に 30 代 $(27.2 \%)$ をピー クとし，20代 (21.0\%) 40代 $(23.1 \%)$ と若, 中年層
に多かった。

5 ) 肥満（図 5 A, 図 5 B)

肥満度は土10\%を, 皮下脂肪厚は右上腕中央外側之 肩甲骨下部の 2 ケ所を測定加算し, 男性 $35 \mathrm{~mm}$ 未満, 女性 $45 \mathrm{~mm}$ 未満を正常範囲とした。肥満度は男女とも 異常者率はあまり差がなかった。男性は，太りぎみ (11 19\%)で, 20 代 $15.8 \%, 30$ 代 $23.6 \%, 40$ 代 $21.6 \%$, 50 代 $19.0 \%, 60$ 代 $14.9 \%, 70$ 代 $13.4 \%$ となり,肥満 $(20 \%$ 以上）は，20代 $28.9 \% ， 30$ 代 $18.9 \% ， 40$ 代 $22.5 \% ， 50$ 代 $17.4 \% ， 60$ 代 $13.4 \% ， 70$ 代 $14.9 \%$ と加令減少する。 女性は太りぎみでは20代 $5.9 \% ， 30$ 代 $24.5 \% ， 40$ 代 $21.7 \% ， 50$ 代 $22.6 \% ， 60$ 代 $18.9 \% ， 70$ 代 $10.7 \%$ と加令 減少するが，肥満は，20代 $17.6 \% ， 30$ 代 $9.5 \% ， 40$ 代 $22.8 \% ， 50$ 代 $21.5 \% ， 60$ 代 $24.8 \% ， 70$ 代 $28.6 \%$ と加令 増加した。

皮下脂肪厚は女性優位であり，20代 $14.7 \% ， 30$ 代 $23.5 \% ， 40$ 代 $31.3 \% ， 50$ 代 $30.6 \% ， 60$ 代 $26.5 \% ， 70$ 代 $29.8 \%$ と 40 代に急増, 50 代以上は横這いであるのに対 乙，男性は，20代 $26.3 \% ， 30$ 代 $12.9 \% ， 40$ 代 $10.5 \%$, 50 代 $9.3 \% ， 60$ 代 $7.9 \% ， 70$ 代 $3.0 \%$ と加令減少した。

6 ) 貧血(図 6)

$\mathrm{Hb}$ は，男性 $13.0 \sim 18.0 \mathrm{~g} / \mathrm{d} \ell$ ，女性 $12.0 \sim 16.0 \mathrm{~g} / \mathrm{d}$ もを正常範囲とした。貧血者は男性が $10 \%$ 以下に対し, 女性は20\%前後と多かった。男性は30代4.1\%，40代 $2.4 \% ， 50$ 代 $5.0 \% ， 60$ 代 $4.8 \% ， 70$ 代 $7.5 \%$ と徐々に増 加するのに詨し，女性は年令差があまりみられず，平
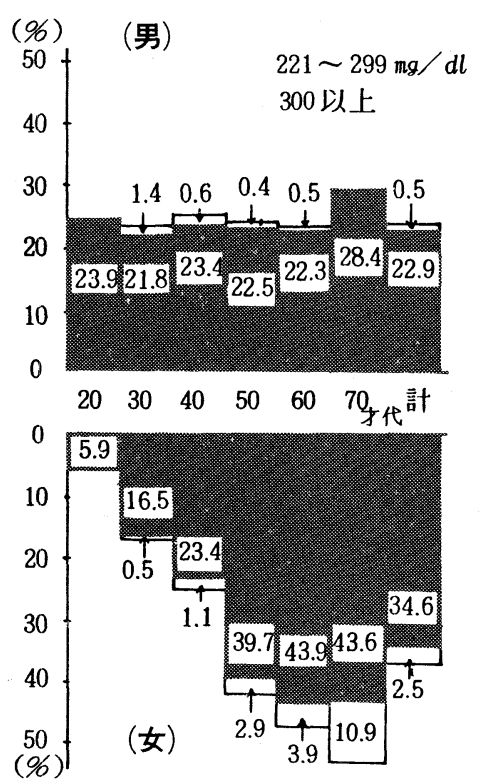

図 3 A. 総コレステロール

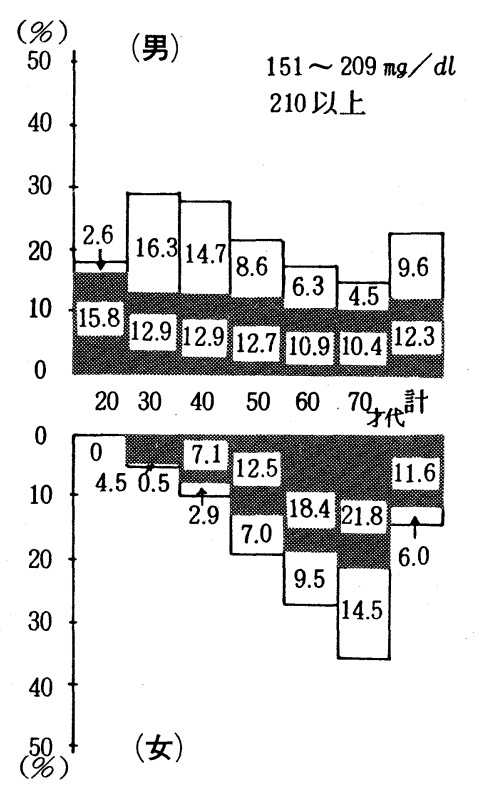

図 3 B. 中性脂肪

\section{（男）}

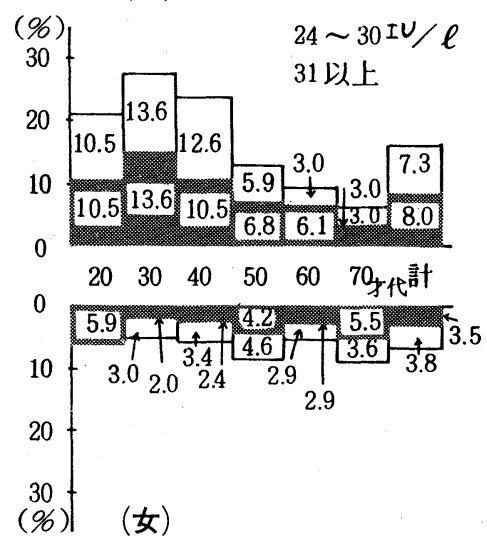

囯 4. $G \quad P \quad T$ 
均化していた。

7 ) 尿検查（図 7 )

蛋白, 糖, ウロビリノーゲンの 3 項目の定性検査を
行なったが，3項目とも年令にあまり関係なく, 男性に 異常者が多かった。しかし, その値も10\%以下と, 他 項目の異常者率からみれば，かなり低かった。

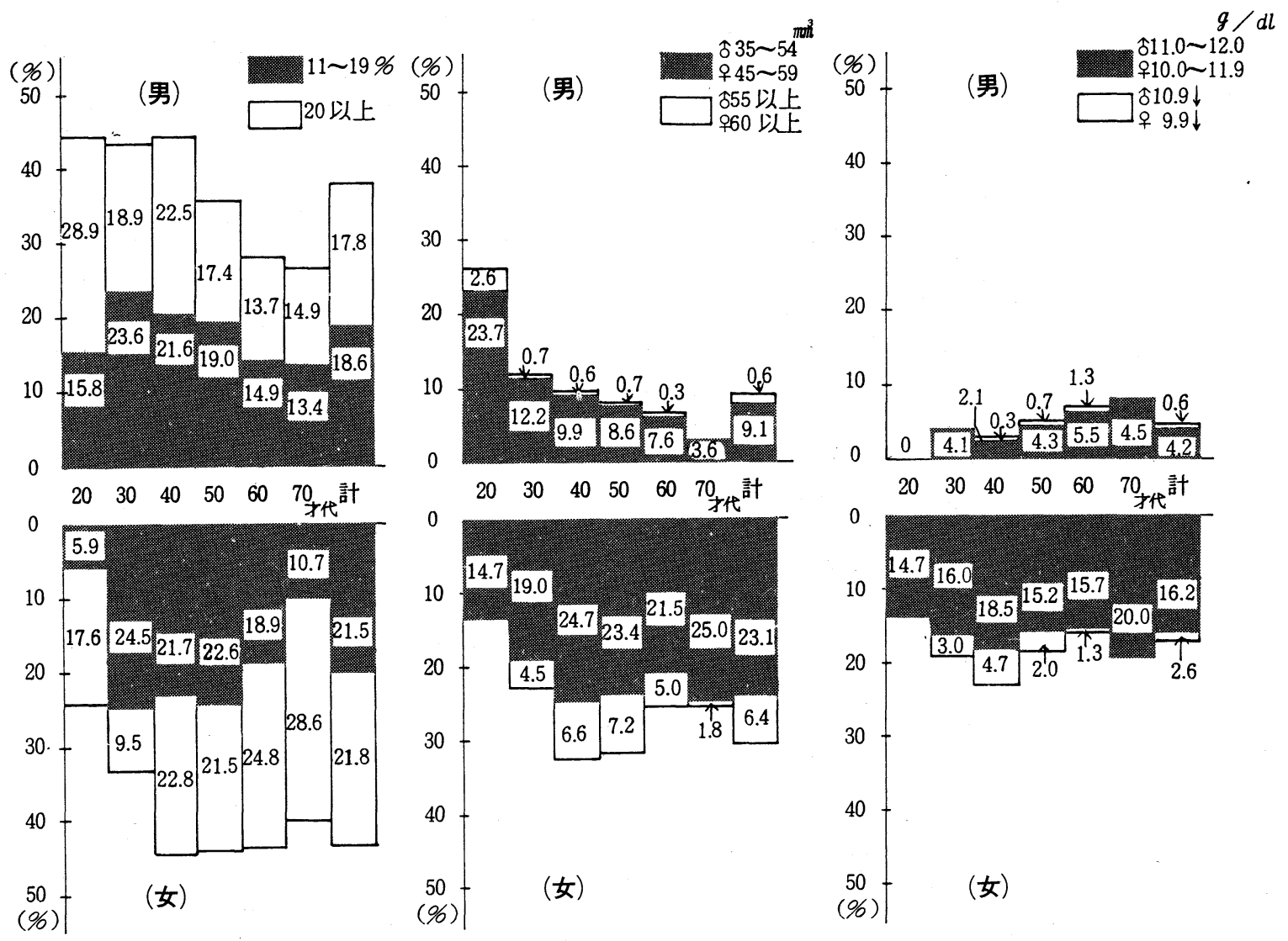

図 5 A. 肥 満 度

図 5 B. 皮下脂肪厚

図 6. $\mathrm{Hb}$ (ヘモグロビン )

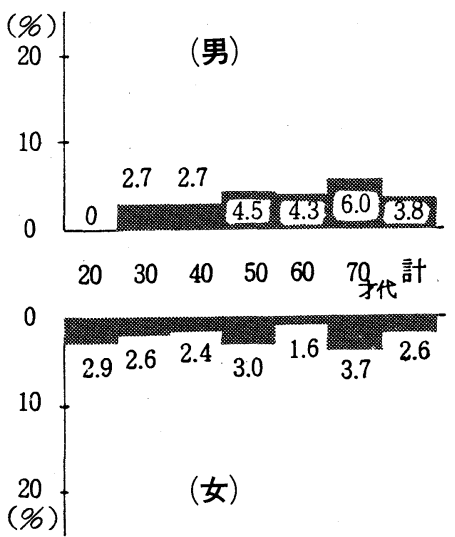

図 7 A. 尿蛋白 陽性

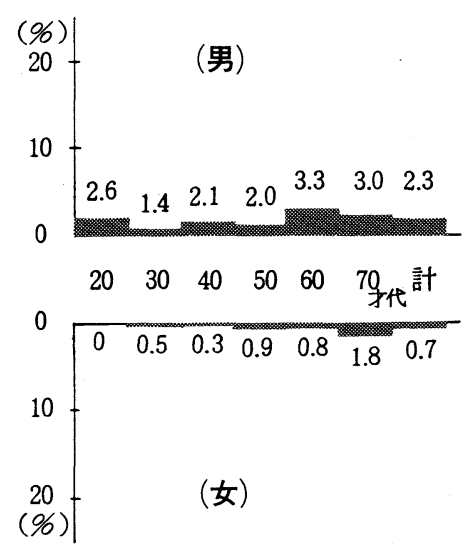

図 7 B. 尿 糖 陽性

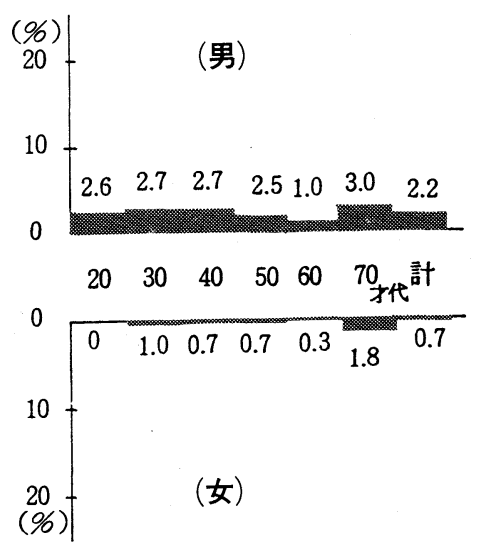

図 7 C. 尿ウロビリノーゲン 


\section{IV. 考}

察

この事業団の検診は, (1)結果がすべて当日のらちに 通知できる。(2)それについての指導が診断とともに行な 壳る。(3)保養をか衫る。(4)検診料, 講話料は一切無料 (事業団が負担), 宿泊費 ( 4,500 円前後) の夕本人が 負担する。などの利点がある。一方, 宿泊を伴らため, 生産形態によっては, 希望したくても参加できないと いらこともあり, 参加者の年令, 性別, 参加時期に偏 りを生じがちである欠点を有する。

肥満者は, 圧倒的に女性に多く, この傾向は田谷ら ${ }^{2)}$ の報告によれば，都市近郊部型農民に打いても男性肥 満者 $17 \%$, 女性肥満者 $22 \%$ であり, 福島県でも同様の 傾向があった。また杉山ら 昭和 55 年の検策でも男性肥満者, 平均 $32.0 \%$, 女性肥 満者平均 $57.5 \%$ と同傾向を示した。肥満を年代別にみ ると, 男性は加令減少する。前述杉山らの報告に和い ても, 昭和 56 年で 20 代 $31.6 \%, 30$ 代 $39.3 \%, 40$ 代 $32.0 \%$, 50 代 $25.0 \%$ であり, 昭和 56 年の報告でも，30代 $15.2 \%$, 40 代 $8.5 \%, 50$ 代 $7.8 \%$ と我々と同様の傾向がみられた。 女性は, 逆に加令増加する。やはり, 杉山ら ${ }^{5 / 6)}$ の報告 でも，昭和55年では，20代 $31.6 \% ， 30$ 代 $37.3 \% ， 40$ 代 $49.2 \%, 50$ 代 $54.3 \%$ であり, 昭和 56 年では, 30 代 $15.7 \%$, 40 代 $18.2 \% ， 50$ 代 $20.2 \%$ と我々と同様に年代を追って 肥満度の増加をみた。また，上田ら ${ }^{5)}$ は，30代 $10.5 \%$,

表 2. GPT と飲酒状況

\begin{tabular}{|c|c|c|}
\hline 飲 酒 & $24 \sim 30$ & $\begin{array}{l}30 \text { 以上 } \\
(\mathrm{IU} / \ell)\end{array}$ \\
\hline 毎 & $37.3^{\%}$ & $38.8^{\%}$ \\
\hline 時 & 35.3 & 34.7 \\
\hline のまない & 27.5 & 22.4 \\
\hline $\begin{array}{l}58 \text { 年度 } \\
\text { を対象 }\end{array}$ & 診におけ & 受診者 \\
\hline
\end{tabular}

40 代 $17.8 \% ， 50$ 代 $28.6 \% ， 60$ 代 $19.6 \%$ であったという。 30５0才代で加令増加し，60才代で減少するが，これ も我々とほぼ同傾向であった。

高血圧, 高コレステロール血症も, 年令に伴って増 加した。加令に加光肥満は健康な生活を営む上で, 種 々 の障害となっているものと思われる。
脂質においては, 総コレステロール, 中性脂肪とも 女性は, 20才代から70才代まで, 加令増加が著しかっ た。前述杉山らによれば，総コレステロール高值は， 30 代 $5.3 \% ， 40$ 代 $7.5 \% ， 50$ 代 $18.1 \% ， 60$ 代 $13.0 \%$ とな り，60才代の減少が我が県と異なった。中性脂肪も 30 代 $2.6 \% ， 40$ 代 $5.0 \% ， 50$ 代 $4.9 \% ， 60$ 代 $2.2 \%$ と我が県 と逆に減少の傾向を示している。

GPT の異常者は男性に多かった。これは掛札ら ${ }^{6} の$ 報告においても男性 $7.3 \%$ ，女性 $4.3 \%$ であり，杉山ら によっても，男性平均 $4.5 \%$, 女性平均 $1.2 \%$ と同傾向 であるが，両報告とも $10 \%$ 以下に対し，我が県では， 平均して $15.3 \%$ であり，ピークの30才代では， $27.6 \%$ を示し異常者がかなり多かった。また男性30才代を ピークとする加令減少は, 杉山らの昭和 56 年の報告で も，30才代 $6.1 \%$ ，40才代 $3.9 \%$ ，50才代 $3.5 \%$ と我々と 同様な傾向を示した。

わが県男性は GPT 同様, 中性脂肪も30才代をピー クとした。58年度実施の検診により, 問診によるアル コール摂取量と GPT の関係を表 2 に示した。アル コールの影響が少なからずあると思われる。

\section{V. 結語}

要精検者は, 総受診者 $(5,344$ 名) の $27.3 \%$ にたる 1,458名だった。このうち医療機関で精検を受診した者 $54.2 \%$ (790名) で，その結果「治療」となった者は 448 名 (56.7\%) だった。精検末受診者の減少に力を入れ たい。また 59 年度は, 事業団事業 5 力年計画の最終年 度にあたるため, 検診受診者の増加に加え, 受診後の 指導及び「早期発見」「早期治療」と健康に対する啓蒙 活動をさらに徹底したい。

\section{文献}

1）東芝徃，東芝メディカル珠：自動化学分析装置，TBA 360型 取扱説明書.

2) 田谷利光ら：茨城県に打ける集団検䛦成績, 日農医誌，28, $240 \sim 241,1979$.

3) 杉山一教ら：新潟県農村に抢ける健康調查成績, 日農医誌, 29, 178 179, 1980.

4）杉山一教ら：新潟県農村に打ける健康調查成績, 日農医誌, 30, 378 379, 1981.

5 ）上田裕子ら：出稼ぎ世帯の成人の健康状態, 日農医誌, 27, $364 \sim 365,1978$.

6) 掛札誠子ら: 秋田県南地方に抢ける健康農村推進に関する 調査研究，第 3 報，日農医誌，26，420 421，19，1977. 


\title{
Report of Health Survey Conducted During 1982 \\ by the Mutual Welfare Association of the Fukushima Pref. Agricultural $\mathrm{Co}^{-}$operative
}

\author{
By Mieko Tanaka*, Mitsuko Shiraishi*, Yoichi Yoshida* \\ Masaki Namatame*, Iwao Komuro*, Sadao Haga* \\ Jiro Tachibana*, Ryoichi Endo*, Shigeharu Kikuta** \\ Katsuya Akanuma***
}

Our examination was performed on 1,541 men and 3,803 women. Reviewed were blood pressure, obesity, anemia, fatty tissue (lipide), liver function, urine-suger and protein, urobilinogen, and their abnormalities.

(1) High blood pressure was found in $53.7 \%$ of the men and $68.3 \%$ of the women, with higher rates found in the middle to older age groups of both men and women.

(2) Obesity, by the Minowa method, was found to be over $20 \%$, with the higher rate being in women. The tendency to obesity in men was found to decrease with age.

In females, abnormalities of blood pressure, total cholesterol, triglyceride, thickness of subcutaneous fatty tissue (of the upper arm and shoulder blade areas) were discovered to be greater in proportion to obesity.

(3) Abnormalities in GPT were seen as $15.3 \%$ in men and $7.3 \%$ in women. According to age group in men: Those in their 30 's, $21 \%$, in the 40 's, $27.2 \%, 50$ 's, $12.7 \%, 60$ 's, $9.1 \%$.

A study on the effects of alcholic beverage consumption will be included in the 1983 survey.

* Institute of Rural Medicine

** Kashima Kosei Hospital

*** Futaba Kosei Hospital 